\title{
SOCIETY WITHOUT A CIVIL REGISTRY (1918-1940): OUTCOMES AND CONSEQUENCES
}

\author{
Regina Laukaityte
}

ABSTRACT This paper analyses the resulting legal situation in the Lithuanian Republic in 1918-1940 when only the clergy of state-recognised religions registered acts of civil status (births, marriages and deaths). This situation created many problems for the small number of believers of 'unrecognised' religions, and non-religious citizens. This paper investigates the different approaches to civil registration by the political forces representing the government. It attempts to explain what solutions society found from the resulting situation, that is, how in the absence of a state registration system of civil status, believers of 'unrecognised' communities and the non-religious population nevertheless married, registered children and buried their dead. The consequences of the dominance of Church registration are also discussed.

All the right and left political parties that ruled the Lithuanian state recognized the importance of the introduction of civil registration: all of them promised and prepared to adopt laws to regulate it. However, by 1940 these laws were not adopted. This was determined by the active opposition by the Catholic Church, and from a religious point of view the quite homogeneous position of the majority of society. The dominance of Church registration radicalised the part of society that was dissatisfied with this, especially the intelligentsia. The Lietuvos laisvamaniu etinès kultūros draugija (Lithuanian Libertines Society) appeared and grew, its initiative spread to establish civil marriage in the Klaipeda region and abroad, and to establish a cemetery for libertines (freethinkers). Although such events were rare, their presence indicates a social change: the trend towards the liberalisation of traditional conservative Catholic culture.

During the interwar period in Lithuania, there was no state registration of acts of civil status, only the clergy of state-recognised religions had the right to register births, deaths and marriages. 
This situation caused many problems for the members of religious communities which did not have official state recognition.* Nonreligious citizens, freethinkers, who lost the mediation of the Church in recording marriages and births, and respectfully burying their dead in cemeteries, which in Lithuania belonged to religious communities, felt discriminated against.

At first glance, the problem of civil registration in the interwar period was not very topical: the overwhelming majority of the population were practising Catholics ( 85.7 per cent), and a relatively small number of people professed other religions.** Only 102 inhabitants filled out the 1923 census as 'atheists' (only seven), 'without religion', 'freethinkers' or did not list any religion. ${ }^{1}$ However, if we are to believe the clergy, the situation during the 20 years of independence changed considerably. In reviewing the situation in 1939, the Rev. Stasys Yla noted that the spontaneous distancing of the populace from the Church occurring in European countries in the 19th and 20th centuries was clearly noticeable in Lithuania. 'It is more than clear that we are already on the road of the apostasy of the masses', ${ }^{2}$ he wrote. As a publicist, Yla probably significantly dramatised the situation; however, such generalisations were apparently driven by the unexpected reaction of society against ecclesiastical regulation. Anyhow, Lithuania was the only country in Europe without civil

* Eight religious communities, Catholic, Lutheran, Calvinist, Orthodox, Old Believers, Jews, Muslims and Karaites, enjoyed privileges of official state recognition in the interwar period. The government paid the salaries of the clergy of 'recognised' religions, assigned allowances and loans to build and repair houses of worship, chaplains of these religions worked in the army, faith was taught in schools, and they were authorised to handle civil status registry. These communities inherited the status of 'recognised' religion from Imperial Russia, which the Republic of Lithuania took over (with the exception of the Old Believers, which the Russian Empire discriminated against).

** There were 30 religious communities in Lithuania, but only seven had more than 1,000 believers. Communities of other faiths were not numerous, they counted only 998 people. The quantitative situation of minorities did not change substantially during the years of independence, but after the acquisition of the Vilnius region the number of believers increased significantly. In 1923, out of a population of about 2,030,000, 1,739,393 were Catholics (85.7 per cent), 155,125 Jews (7.65), 66,578 Lutherans (3.28), 32,149 Old Believers (1.59), 22,925 Orthodox (1.13), 10,678 Calvinists (0.53), 1,107 Moslems (0.05). See: Lietuvos gyventojai: pirmojo $1923 \mathrm{~m}$. rugsèjo $17 d$. visuotino gyventojų surašymo duomenys (Kaunas [1924]), p. XL.

${ }^{1}$ Lietuvos gyventojai: pirmojo $1923 \mathrm{~m}$. rugsejo $17 \mathrm{~d}$. visuotino gyventoju surašymo duomenys, pp. 30, 34.

${ }^{2}$ S. Yla, 'Kunigas ir liaudis', Tiesos kelias (1939), no. 11, p. 773. 
registration (in Latvia, laws regulating civil registration were adopted in 1921, in Estonia in 1922, in Poland Church registration dominated, but local administrative institutions registered the civil status of people not connected with religious communities; in most West European countries, even in Catholic Italy, Spain and Portugal, civil registration was begun in the 19th century, in Protestant countries from the 17 th century).

The purpose of this article is to explore some of the political and social aspects of the dominance of Church registration in Lithuania in 1918-1940: 1) to analyse the different political forces representing the government's approach to civil registration; 2) to find out what kind of outcomes were found in the situation, i.e. in the absence of a system of state registration, how did the believers of 'unrecognised' communities and non-religious residents, nevertheless, marry, register their children and bury their dead; 3) to ascertain what the consequences were of the dominance of Church registration, to perceive the pressure encouraged by this situation on the development of society and the state and the Lithuanian Catholic Church. These aspects of the dominance of Church registration have not yet been analysed in historiography, most attention has been devoted to the constitutionalisation of marriage, i.e. the consolidation of legal questions in the Constitution. ${ }^{3}$

\section{Attempts to legalise civil registration}

In the interwar period, the problem of civil registration was a frequent topic of party disputes in the Seimas, and in the press. In 1922, when the Constituent Seimas adopted the Constitution by the votes of the Christian Democrats, those in power promised to pass laws normalising acts of registration. ${ }^{4}$ However, later the Christian Democrats did not propose any laws in this field in the Seimas, the practice of registration by the clergy of 'unrecognised' religions was also not discussed. In fact, in the spring of 1924, the government

${ }^{3} \mathrm{~K}$. Valančius, 'Bažnytinès (kanoninès) santuokos institucionalizacija ir konstitucionalizacija: raida ir problemos', Lietuviu kataliku mokslo akademijos metraštis 19 (2001), pp. 267-282; R. Juozapaitienè, 'Bažnytinès santuokos registracija Lietuvoje: istorija ir dabartis', Kultūra ir visuomene. Socialiniu tyrimu žurnalas (2011), no. 2 (3), pp. 101-123.

${ }^{4}$ Speech of the deputy chairman of the Seimas Rev. Justinas Staugaitis at the 18 July 1922 session of the Constituent Assembly (Seimas), Steigiamojo Seimo darbai, book 44, 218 meeting (Kaunas, 1922), p. 102. 
tried to introduce an alternative to civil registration: on 8 April the minister of internal affairs Karolis Žalkauskas issued a government circular, by which the boards of cities and rural districts (based on the precedent that existed in Imperial Russia, when state institutions administered the registration of Old Believers and 'sectarians') were appointed to administer the registry books temporarily. Until the necessary laws were passed, they were authorised to enter birth, marriage and death records in books of the form prescribed by the Ministry of Internal Affairs. The circular also provided that citizens not belonging to religious organisations (i.e. parishes, communities of various faiths) would be buried in a specially designated area of the nearest cemetery. ${ }^{5}$

It would appear that the minister's circular could have not just temporarily, but actually put in order the practice of civil registration and of the burial of the population, but the Curia of the Diocese of Žemaitija opposed it. In a letter to the prime minister, Bishop Juozas Skvireckas pointed out that the circular was contrary to the existing laws and the canons of the Catholic Church, and demanded its recall. ${ }^{6}$ The new Christian Democratic government did this (on 14 January 1925). ${ }^{7}$

How did the circular of the minister K. Žalkauskas work? Was there time to apply it? It seems that there were several instances of its application in the period of Christian Democratic rule. ${ }^{8}$ It was remembered again after the Left (the Peasant Populists and the Social Democrats, who ruled until the 17 December coup) won the elections in May 1926. Their government immediately began to block Church registration. Not recognising the ecclesiastical province of Lithuania created by Pope Pius XI in the spring of 1926 and the new bishops appointed, the leftist government decided in August not only not to pay salaries to the clergy, but also not to validate the civil status acts issued by the legally 'non-existent' curia of the Kaunas archdiocese. ${ }^{9}$

${ }^{5}$ Circular no. 2779 of the minister of internal affairs of 8 April 1924 to district and city boards and district governors, Vyriausybès žinios (1924), no. 157, eil. no. 1117.

${ }^{6}$ Letter of Bishop J. Skvireckas of 29 October 1924 to the prime minister, LCVA, fund 923, ap. 1, b. 428, 1. 315.

${ }^{7}$ M. Kavolis, Bažnytinès tikybiniai mišriosios ir civilinès moterystès juridine padetis Lietuvoje (Kaunas, 1930), p. 17; 'Nauji Lietuvos klebonai', Rytas (1926), no. 87, p. 4.

${ }^{8}$ L. Purènienè, Jungtuvès ir išsiskyrimai (Kaunas, 1932), p. 91.

${ }^{9}$ Letter of the head of affairs of the Cabinet of Ministers on 2 August 1926 to the minister of internal affairs, LCVA, f. 923, ap. 1, b. 495, 1. 67. 
Then, apparently, the circular of the minister K. Žalkauskas was remembered, the legitimacy of the cancellation of which was questioned, because it was never published in Vyriausybès žinios (Government Gazette). Information about one case of civil marriage remained in the press and archives at that time: in June 1926 the Siauliai city mayor Jackus Sondeckis registered it. Information about those marrying was originally publicised by peculiar banns: for a week an announcement was posted in the office of the municipality. ${ }^{10}$ The newspaper of the Christian Democrats Rytas commented on this news item in an article with the biting title 'New Lithuanian Pastors'. 11 However, when the couple asked that the data about their marriage be recorded in their passports, a bureaucratic correspondence with the Citizens' Protection Department of the Ministry of the Interior began, officials of which decided nearly a year later under the rule of the Nationalists that because there was no law for civil marriages their marriage was not valid. ${ }^{12}$ So the first attempts to introduce civil registration by the efforts of the government failed.

Although the left did not rule for a long time, they nevertheless rushed to draft a registration law by the middle of September 1926, and in November the minister of internal affairs presented it to the Seimas. ${ }^{13}$ Although the project provided that a marriage could be recorded by either the heads of registration of the local governments of cities or district municipalities, or the clergy (Church registration was preserved), the steps taken by the leftist government provoked a stormy reaction by the Church and Catholic parishes. Protests expressed at meetings of parishes and Catholic organisations were sent to the government on a huge scale. In them, among other complaints to the government, was the demand to stop the registration law, which, according to one parish representative 'will increase the number of infidels, expand public harlotry, erode virtue and destroy families'. ${ }^{14}$ The military

${ }^{10}$ Ibid.

11 'Nauji Lietuvos klebonai', Rytas, 1926, no. 87, p. 3.

${ }^{12}$ Letter of the Šiauliai city and district governor on 10 February 1933 to the Ministry of Education, LCVA, f. 391, ap. 4, b. 87, 1. 56.

${ }^{13}$ Order no. 38 of the minister of internal affairs on 15 September 1926, LCVA, f. 377, ap. 9, b. 75, 1. 16. The directors of the Ministry of Internal Affairs Citizens' Protection and Local Government departments and the adviser for affairs of religions made up the commission.

${ }^{14}$ Protest of the Catholics of the Stakliškes parish to the Cabinet of Ministers (undated, 1926), LCVA, f. 923, ap. 1, b. 480, 1. 103; see the analogous letters of 
coup of December 1926 prevented the Left from adopting laws in the Seimas related to civil registration.

After strengthening their position in the government, the Nationalists inherited not only the problem of civil registration, but also public opinion for its validation polarised to the extremes. They did not avoid making promises to introduce civil registration, each time provoking protests by the Church, the faithful encouraged by the clergy, and the Christian Democrats who were in opposition. Catholic priests published many books and brochures aimed at the people, and the bishops published pastoral writings in which they argued that civil marriage was incompatible with canon law and the provisions of the Lithuanian concordat with the Vatican, and spoke of the disastrous consequences for the nation and the state. ${ }^{15}$ Nevertheless, in February 1940, the Commission of the State Council of Civil Rights did prepare a civil registration law, which also guaranteed the alternative of church registration. The Church again condemned this law as providing a possibility for divorce, and government interference in the regulation of Catholic marriages. ${ }^{16}$

So, in spite of the peculiar liberalism of Lithuania's legal environment (the Constitution of the Republic did not deny the possibility of introducing state registration, discussions took place, and more than one variation of laws governing the option was developed), citizens of the state in 1918-1940 lived without civil registration. The parties of the right that held political power the longest were unwilling to deepen the conflict with the Catholic Church, and did not force the adoption of the laws. The vast majority of the public, of course, did not feel much discomfort about the situation, and used Church registration, but some residents still sought ways to circumvent the gaps in the law and create legal precedents. What recourses were found?

representatives of Catholic organisations of the Kretinga district, of various parties and organisations of the city of Panevėžys and its surroundings, in 1926 (ibid., 1. 166, 150); statements to the commission of Seimas petitions, in 1938, LCVA, f. 391, ap. 4, b. 741, and others.

${ }^{15}$ M. Krupavičius, Civilinès jungtuvès (Kaunas, 1933); P. Malakauskis, Moterystè (Kaunas, 1933); V. Brizgys, Vadinamosios civilinès jungtuvès proto, teisès ir istorijos šviesoje (Marijampolè, 1936); V. Brizgys, Civilinès metrikacijos klausimu (Marijampolè, 1939); J. Vislickis, Civilinès jungtuvès (Kaunas, 1939); K.K.O. [Kazimieras Olšauskas], Mintys pamokslui apie civilinę metrikacija (Telšiai, 1940).

${ }^{16}$ [K. Olšauskas] Apie civilinès santuokos įstatymo projektą, Tiesos kelias (1940), no. 3, pp. 149-152. 


\section{Registration of Acts of Civil Status not in the Catholic Church}

The practice of registration of religious communities 'not recognised' by the State As was mentioned, the Lithuanian Constitution provided that believers would record births, marriages and deaths with their clergy, and were not compelled to repeat it in another institution. Moreover, the Constitution of the Republic gave all religious organisations the right to manage matters according to their canons or statutes, ${ }^{17}$ so it would seem that the clergy of all the religions that existed in the country were able to perform acts of Church registration. However, the situation was much more complicated, because, as has been mentioned, there were more than 20 religious communities officially 'unrecognised' by the state without the rights of a legal entity.

Despite the fact that laws regulating the emergence and functioning of such communities were not adopted in the Republic of Lithuania, the state could not ignore the fact of their existence. Formally, the not legalised religious communities one after another started carrying out Church registration. For example, the Baptists (in 1927 there were about 380 of them in Lithuania) made registration entries without official authorisation until 1932, when a registry office opened. ${ }^{18}$ The Methodist Episcopal Church (it had about 250 members) received registration forms from the advisor of the affairs of religions in 1924. ${ }^{19}$ In 1929 the Ministry of Education allowed the Adventists (there were about 200, legally recognised as a religious community in 1927) to keep registry books. ${ }^{20}$ The Lithuanian Evangelical Christian Association (Pentecostalists, it had about 150 members) in the Biržai district received a similar permit, in fact temporary, in $1930 .^{21}$

Thus, the state managed to 'neutralise' the religious communities, at least the more numerous ones. The 'unrecognised' religious

${ }^{17}$ Lietuvos Valstybès Konstitucija su paaiškinimais (Kaunas, 1922), pp. 16-17; Lietuvos Valstybès Konstitucija (Kaunas, 1928), pp. 11-12; Lietuvos Konstitucija (Kaunas, 1938), pp. 6-7.

${ }^{18}$ V. Brizgys, Civilinés metrikacijos klausimu, p. 12.

${ }^{19}$ Letter from the adviser for affairs of religions Kazimieras Prapuolenis of 26 April 1924 to the Board of the Methodist Episcopal Church, LCVA, f. 391, ap. 4 , b. $732,1.27$.

${ }^{20}$ Letter from V. Soblys, the Ministry of Education Department of Religious Affairs director, of 9 March 1940 to the Department of Administrative Affairs, LCVA, f. 391, ap. 4, b. 629, 1. 1.

${ }^{21}$ Letter from the head of the Biržai district of 21 December 1934 to the Civil Protection Department, LCVA, f. 394, ap. 1, b. 511, 1. 6. 
communities individually secured permission from the government to conduct registration, and at the end of the period the problem of civil registration essentially remained relevant only to the smallest religious groups and non-religious citizens.

The issue of the legalisation of marriage The most important hindrance to the introduction of state civil registration, was, of course, the registration of marriages. Civil marriage was absolutely unacceptable to the Catholic Church, not tolerating divorce and the intervention of the state in the area of Church marriage. According to Bishop V. Brizgys, 'the Church, and not the state, manages the marriages of all [author's emphasis] baptised persons. The state has the power to handle the matrimony of only unbaptised people, but on the condition that they be considered as sacred, indissoluble and one-to-one. ${ }^{22}$ The Church ignored for a long time the first generation of freethinkers in Lithuania, because they had still been baptised, and in accordance with the doctrine of the Church were bound by ecclesiastical law. Moreover, the clergy treated their statements for the validation of civil registration as the pretensions of a small and not influential group: 'Can the $85.72 \%$ Catholic population in Lithuania allow a handful of infidels to put them to sleep and terrorise them', ${ }^{23}$ asked the Rev. Mykolas Krupavičius rhetorically in a booklet aimed at the populace.

The Catholic Church viewed sceptically not only civil marriages, but also those conducted by the clergy of other religious communities, without doubt the 'certainty' of other religions, for the latter provided many conditions enabling divorce. A result of this was the bigamy cases heard by Lithuania's courts in the interwar period when people leaving their spouses married in the Catholic Church. For their preceding marriage (concluded in a different religious community or civil) was treated as invalid. ${ }^{24}$

People for whom Church marriage was not acceptable due to beliefs or canonical obstacles sought ways to circumvent it. A popular practice became the registering of marriages in the Klaipeda region (where only civil registration was valid) or in foreign countries; for

${ }^{22}$ Brizgys, Civilinès metrikacijos klausimu, p. 12.

${ }^{23}$ Krupavičius, Civilines jungtuves, p. 87.

${ }^{24}$ G. Rutenbergas, 'Dabartinè šeimos teisès padètis Lietuvoje', Teisé (1938), no. 38 , pp. $225-226$. 
example, by famous writers. Vincas Mykolaitis-Putinas married in Riga, Salomejja Nèris in Paris, Antanas Venclova in Klaipeda.* The Supreme Tribunal of the Republic of Lithuania adopted a special resolution $^{25}$ in 1930 on the legal power of marriages registered in the Klaipeda region: this shows that the phenomenon was widespread. According to the Supreme Tribunal, the Republic of Lithuania, taking over Imperial Russia's civil code of Church marriage, 'did not know' civil marriages, i.e. it did not regulate them, but they were not prohibited by any law. Since all Lithuanian citizens, even those who did not live in the Klaipeda region, had the right to all the civil rights enjoyed by the local population, then civil marriages conducted there were in force in the entire country, like those made abroad. The Supreme Tribunal also declared that the Church marriage of Lithuanian Catholic citizens was indissoluble, and divorces registered abroad did not have any legal power in Lithuania. ${ }^{26}$

Meanwhile, the Catholic Church did not recognise civil marriages or divorces made in the Klaipeda region (or anywhere else). 'We know that in the Klaipeda region, some of our Catholics were married civilly. However, their civil marriage both in the eyes of the Church and of God is not a sacrament, not a true contract of matrimony, but only registered public concubinage - thus a sinful, dissolute life', ${ }^{27}$ claimed a popular brochure. The different treatment of legal acts in the institutions of the state and the Church (the latter actually dealt with cases related to the marriages of Catholics) shows that a crisis was maturing in this area. The conflict sooner or later had to be resolved.

There were also other attempts to 'break through' the ice for civil marriage in Lithuania: to create a precedent when the fact of

* The condition that one of the future spouses had to be a local resident made marriage in the Klaipeda region, joined to Lithuania in 1923, more difficult. But this condition was easily bypassed: after successfully registering one's passport temporarily in Klaipeda, one could soon afterwards ask the police for a certificate of the place of residence and marry (letter of Vincas Krève of 18 September 1936 to Saulute [S. Nėris], LNMMB Manuscript Division, f. 4, b. 193, 1. 1). Not only intellectuals used the possibility of civil marriage in Klaipeda, this is reflected in literature - see: V. Petkevičius, Paskutinis atgailos amžius, vol. 2 (Vilnius, 1982), pp. $28-29$.

${ }^{25}$ Resolution of the Supreme Tribunal of the Republic of Lithuania on 13 November 1930, LCVA, f. 391, ap. 4, b. 710, 1. 4-5.

${ }^{26}$ Ibid., 1. 5.

${ }^{27}$ K.K.O. [Kazimieras Olšauskas], Mintys pamokslui apie civilinę metrikacija, pp. $7-8$. 
registration was replaced by disclosure to the public. For example, in 1935 on the front page of the newspaper of the Peasant Populist Lietuvos žinios, there was an announcement by which a couple from the village of Sodeliukai (Padubysys rural district, Šiauliai district) announced to the public of Lithuania their not wanting to 'break their free beliefs in the church' regarding their marriage from 30 November as a fait accompli, until they legalise it after the adoption of a civil registration law. ${ }^{28}$ The Lithuanian Libertines Society, which consisted of atheists, recommending that the facts of marriage be publicised in the press, supported this behaviour. ${ }^{29}$ However, it is difficult to find more data on the spread of this practice in Lithuania.

Although the sacramental Church marriage of Catholics was indissoluble, people found ways to circumvent the canons: some were prepared to change their religion. For instance, according to Bishop Petras Būčys, intellectuals in Kaunas would convert to Orthodoxy. ${ }^{30}$ According to the Peasant Populist daily newspaper Lietuvos žinios, due to the 'obstinancy of priests against civil registration', Islam became 'one of the most fashionable religions'. ${ }^{31}$ This information is

${ }^{28}$ (Announcement) Lietuvos žinios (1935), no. 275, p. 1.

${ }^{29}$ A. Žukauskas, Laisvamanybès pagrindai (Kaunas, 1939), p. 30. It seems that this practice was taken over from the USA, where in many states a publicised marriage was considered to have taken place (see: L. Purénienè, Jungtuvès ir išsiskyrimai, p. 81).

${ }^{30}$ P. Būčys, 'Rusai stačiatikiai ir sentikiai Lietuvoje', Lietuviu kataliku mokslo akademijos suvažiavimo darbai, vol. 2 (Rome, 1973), p. 133. 'A very interesting phenomenon in Kaunas, not observed anywhere else, is the conversion of $\mathrm{Li}$ thuanian intellectuals to Orthodoxy after 1918, i.e. in the period of Lithuania's independence. I have not learned of any such instance that was not tied to the divorce of a marriage that could not be obtained in the Catholic Church, but there is a quite significant number of conversions to Orthodoxy related to the divorce of marriages,' wrote Eastern Rite Bishop Būčys.

31 'Iš musulmonu gyvenimo', Lietuvos žinios, (26 02 1938), access through the Internet $<$ http://www.epaveldas.lt/recordText/LNB/LNB00D2D8A3/Vas.26. pdf? exId=83011\&seqNr=1> [observed on 2810 2013]. 'Mostly Catholics began to go to Islam, some for divorce and marriage, others for children whom they do not want to baptise. Moreover, many are attracted by the great tolerance of this religion in our conditions. A Catholic converting to Islam can, according to his wish, not be circumcised, because it can be replaced by prayers and offerings to the glory of the Prophet, in Catholic terms, a kind of Peter's Pence. Moreover, converting to Islam with the goal of a new marriage, it is not necessary to divorce the old wife, because the Moslem religion allows one to have several wives, and the constitution respects all the rights of believers and allows one to perform duties of faith [...] The Moslems welcome the rows they supply, the ascension and interest.' 
obviously exaggerated; apparently, it was intended more to shock the public and draw attention to the problem than to reflect real trends.

The problem of the registration of children The registration of births is an especially important area for the state, relating to population statistics, inheritance rights, and military obligations. Sources indicate that in the absence of civil registration, there was a lot of chaos. Some non-religious parents, not wanting to baptise their newborn babies in a church, often just did not register them, waiting for the introduction of civil registration procedures.

For some time, notaries (after receiving a statement by the parents confirmed by the signatures of two witnesses) would write birth certificates for unbaptised children; however, this practice was prohibited. ${ }^{32}$ When birth certificates became necessary for school-age children, the parents tried to legitimise them through the courts, ${ }^{33}$ others wrote to the central authorities, urging that conditions for registering grown children be allowed more rapidly. ${ }^{34}$ Namely, the laws of the state did not provide for a procedure to legitimise children without Church registration. One had to turn to the court, or such children could be baptised and receive Church registration certificates.

The approach of the Catholic Church to children of parents who had had a civil marriage was unambiguous: 'All who are born of Christians not having adopted the sacrament of Matrimony, from the aspect of natural and Church laws are illegal,'35 affirmed Bishop V. Brizgys. Therefore, the writer Petronèlè Orintaite was not in error, when she doubted that there was a legislative decree that infants born

32 'D-ro J. Šliūpo peticija Seimui. Duokite mums civilinės metrikacijos įstatymą', Lietuvos žinios (1938), no. 284, p. 5.

${ }^{33}$ Y.X., 'Laisvamanių suvažiavimas Šiauliuose', Tiesos kelias (1936), no. 4, p. 198; 'D-ro J. Šliūpo peticija Seimui. Duokite mums civilinès metrikacijos istatymą', Lietuvos žinios (1938), no. 284, p. 5. (J. Šliūpas presented the incident in a petition when the court legitimised two school-age children after the parents presented a civil marriage certificate in the presence of two witnesses.

34 'My eyes have already stretched while waiting for civil registration. My son Vytautas is growing nicely, but he is not registered anywhere,' wrote the founder and leader of the freethinkers movement Jonas Šliūpas to the chairman of the Ministry of Internal Affairs Department of Religious Affairs in 1931, (LCVA, f. 391, ap. 4, b. 735, 1. 4); letters from Libertines Society members Kazys Bružas (from the village of Rukai in the Kretinga district) and Bronius Kasperavičius (a clerk from Biržai) to the MIA (ibid., pp. 9, 57). In their families there were also children one to eight years old without birth certificates.

${ }^{35}$ V. Brizgys, Vadinamosios civilinès jungtuves, p. 90. 
into a family whose parents had made a civil marriage be recorded in Church registries in the mother's name: 'Then this bugaboo of civil registration was demagogically inflated in society? For example, my friend P. Dielininkaityte (the sister of Dr Pranas Dielininkaitis. R.L.) married civilly in Riga around 1932, and complained to me that while there is no civil registration law, the children born of such marriages are recorded under the mother's maiden name, that is, as real illegitimate children. Therefore, many of these spouses, like themselves, are so far avoiding having children, waiting impatiently for the new law, ${ }^{36}$ she wrote in her memoirs. 'But it is likely that a similar arbitrariness may have occurred here and there registering a newborn in church offices. Also, similar gossip could have been allowed deliberately, to discredit civil marriage or to put people off it', she added. ${ }^{37}$

The issue of the burial of the dead If believers of "unrecognised' religions still had their own cemeteries, then irreligious citizens, freethinkers in this case, were in a real dead-end. Their behaviour was a real propaganda treasure for their opponents. For instance, in 1926, on the first page of the Christian Democrat newspaper Rytas (Morning), one could read that after the death of his father, the former president Kazimieras Grinius 'buried the deceased in his field and made a speech. ${ }^{38}$ It seems there were many unofficial burial sites in Lithuania, appearing after parish priests refused to bury those distant from the Church, suicides and unbaptised infants in the cemetery (on sacred ground). One can make the assumption that the urgency of the problem was mitigated somewhat by the numerous village cemeteries where the remains of those not meeting the standards of religion rested.

How did people behave after the clergy refused to bury their family members? Such occurrences were probably isolated in interwar Lithuania. The relatives of the deceased usually made considerable efforts to bury them normally. Most priests probably did not dramatise the situation, and buried the dead with religious rites in the cemetery, only once again during the sermon reminding Catholics of the teachings of the Church. Nevertheless, the leftist press,

${ }^{36}$ P. Orintaitè, Ka laumès lèmé (Vilnius, 1993), p. 117.

${ }^{37}$ Ibid.

38 'Kaip valstiečių liaudininkų vadai laidoja savo mirusius tèvus', Rytas (1926), no. 87 , p. 1 . 
especially Lietuvos žinios of the Peasant Populists, wrote frequently about conflicting situations not lacking in actual examples. Perhaps in such cases, adults and unbaptised children were usually buried on private land. ${ }^{39}$

There were instances when after a disagreement with the priest, the relatives of the deceased would approach the local bishop, arguing that they were neither heretics nor Freemasons. ${ }^{40}$ Other people even collected signatures, testifying that the deceased was not hostile to religion, baptised his children, and so on, although he himself did not practise it. ${ }^{41}$ It may be that the community of Catholic parishes and the clergy did not bother about the burial of unbaptised infants and other tragic victims near the graves of other family members in a consecrated cemetery. Nevertheless, such an action could result in a court judgment. For example, the case of Albinas Simonavičius, who lived in the village of Paketūriai in the Kupiškis district, continued for several years, when without Church rites he buried an unbaptised infant in the family tomb. ${ }^{42}$

${ }^{39}$ Y.X., 'Laisvamanių suvažiavimas Šiauliuose', Tiesos kelias (1936), no. 4, pp. 196-199. For instance, in 1925 after the priest at Dusetos did not allow in either the town or a rural cemetery the burial of a member of the rural district board who had not made confession, his grave was on the family's farmstead. In the same year, a betrothed couple who shot themselves were buried on a hill near the forest of Daučiunnai, when the priest of Obeliai refused to bury them, 'those distant from the church', in the cemetery (probably due to an unfortunate incident, a young man, the owner of the Daučiunai manor, and then a girl working as a teacher shot themselves) ('Futbola, Katalikiški Dusetų klebono darbai', Lietuvos žinios (1925), no. 121, p. 2, Petras, 'Skaudi tragedija', ibid., no. 259, p. 2).

${ }^{40}$ Petras, 'Skaudi tragedija', Lietuvos žinios, no. 259, p. 2.

${ }^{41}$ Letter from 13 believers to the Bishop of Panevezzys, Kazimieras Paltarokas, LVIA, f. 1650 , ap. 1, b. $80,1.85$. The bishop did not allow the burial with religious rites of a not-practising lawyer.

${ }^{42}$ Learning about the burial, the priest challenged Simonavičius in the court, demanding the removal of the remains of the unbaptised from the consecrated Catholic cemetery. In July 1935 the Kupiškis court sentenced Simonavičius to nine months of simple imprisonment (under Article 73, paragraph 1, and Article 554 of the Criminal Statute) and ordered the infant's remains to be removed from the cemetery, and if he did not do that, to instruct the police to do it at his expense. Simonavičius was arrested in the courtroom, but released on bail. After an appeal at the Panevėžys district court, the latter on 13 May 1936 reduced the sentence to two weeks of simple imprisonment. Simonavičius appealed against this decision to the Supreme Tribunal, which sent the case back to the District Court, indicating that during the burial of the infant the other coffins were not touched and such a burial does not offend the Church. The verdict of the Supreme Tribunal prompted the Panevėžys district court to acquit Simonavičius ('Iš teismo salès', Lietuvos 
In the $1930 \mathrm{~s}$, the problem of the burial of non-religious citizens apparently lost its relevance. Due to the efforts of the Lithuanian Libertines Society, cemeteries appeared which were open, ${ }^{43}$ and the rituals for funerals (with music and speeches) were formed.

\section{The Social Consequences of the Dominance of Church Registration}

In an effort to isolate the public from the influence of people of other faiths and non-religious persons, the Catholic Church most likely went too far. Opposing divorce, it generally dismissed the alternative of state civil registration that were relevant to some citizens. The Church did not appreciate the situation, that its categorical position, contempt for 'a handful of infidels', was in fact not directed against an insignificant and small part of Lithuania's public, but against the intelligentsia. The latter did not remain in debt: it was able to focus and organise a 'front against clericalism', the repercussions of which are reflected in the history of Lithuania's press of the left, political parties and public organisations, and denominational and public schools.

The long struggle of the Church with the intelligentsia gradually included broader social layers: in 1924, in Šauliai, the Libertines Society appeared, which in a few years was able to set up some 50 sections, and civilian cemeteries even appeared in remote towns and villages.* Initially consisting of like-minded intellectuals, the society rather quickly 'entered' the village: as the commentator of the Church's official newspaper Tiesos kelias noted, unlike previous freethinkers congresses, at which intellectuals gathered, the one taking place in

žinios, (1938), no. 8, p. 7). This case resounded widely: in 1935 the Ministry of Education received a letter from Chicago Lithuanians who were angered by the court judgment, and demanded Civil Registry and open cemeteries (letter from Chicago Lithuanians of 4 November 1935 to the Ministry of Education, LCVA, f. 391 , ap. 4 , b. $89,1.110)$.

43 'Žemaitès laisvamanès laidotuvès', Lietuvos žinios, (31 12 1929); a non-religious female resident of Plungè was buried in the cemetery of the Šiauliai freethinkers. By the way, after several years such a cemetery was also opened in Plungé.

* The first opened in Ginkūnai near Šiauliai in 1923, and later at least 12 more (near Kaunas at Žemieji Kaniūkai, Kupiškis, Plungè, Kretinga, Girkalnis, Žagare, Rukai village in the Kretinga district, Lenkimai village in the Skuodas district, Padvarninkai village in the Anykščiai district, near Pagramantis village in the Taurage district, and Vadžgiris village in the Jurbarkas district). 
1936 was 'almost entirely a congress of country people. ${ }^{44}$ According to the probably greatly exaggerated calculations of the freethinkers themselves, there were 10,000 to 15,000 like-minded people in the country. ${ }^{45}$ Their requests to government institutions, demands to equate the rights of citizens and to introduce civil registration, did not stop. ${ }^{46}$

The success of the Catholic Church in opposing the introduction of civil registration determined its image as a conservative institution; even more, it contributed to the critical evaluation of the interwar Lithuanian state. As has been mentioned, citizens of Lithuania were the only ones in Europe that did not have alternative registration. 'It is shameful when you are forced to admit that there was no civil registration in independent Lithuania. Lithuania's Church has a great responsibility here; but one cannot justify Lithuania by saying that our priesthood was dark, because the priesthood is a Lithuanian product, ${ }^{47}$ Algirdas Julius Greimas wrote in 1962, then a young university professor, but already known as a linguist and semiotician, replying to a question from Metmenys, 'What is the specific aspect or event in the life of independent Lithuania of which you are personally most ashamed?'

Despite the concerns mentioned about the 'apostacy of the masses', if by 1940 the Republic of Lithuania had organised a referendum on civil registration, the absolute majority of the population, without doubt, would have opposed it. Nevertheless, an institution of civil registration was essential for the state as an unchallenged principle

${ }^{44}$ Y.X., 'Laisvamanių suvažiavimas Šiauliuose', Tiesos kelias (1936), no. 4, p. 196.

${ }^{45}$ Letter of J. Šliūpas on 16 November 1931 to the chairman of the MIA Department of Religious Affairs, LCVA, f. 391, ap. 4, b. 735, 1. 4.

${ }^{46}$ Memorandum signed by 35 renowned scholars, lawyers, physicians to the prime minister, the ministers of justice, education and internal affairs (not dated, beginning of 1940), ibid., b. 92, 1. 96. The participants of the congresses of freethinkers, members of the Libertines Society and individual persons sent analogous letters.

47 'Nepriklausomoji Lietuva šiandieniniu ịvertinimu', Metmenys. Jaunosios kartos kultūros žurnalas (Chicago, 1962), no. 5, p. 81. One should not place all responsibility for the opposition to civil registration only on the 'priests'. Discussing the projects of the laws related to it, unambiguous instructions were received in Lithuania from the Holy See, urging the bishops to protest collectively (letter from Cardinal E. Pacelli of 28 April 1937 to A. Arata; Report of A. Arata of 8 March 1938 to Cardinal E. Pacelli, Lietuva ir Šventasis Sostas (1922-1938). Slaptojo Vatikano archyvo dokumentai, sud. A. Streikus (Vilnius, 2010), pp. 576, 596-597). 
of freedom of conscience, an indicator of the maturity of the state and society.

\section{Conclusions}

Obviously, all the right and left political parties that ruled Lithuania in 1918-1940 evaluated the importance of the introduction of civil registration: all promised and prepared to adopt laws regulating it. The need to do this was forced most by the situation whereby some citizens did not have the opportunity to register civil status, and the fact that the state and the Church treated legal acts differently (the latter actually decided cases related to marriages of Catholics and did not recognise civil marriages made in the Klaipeda region or abroad). So a crisis developed in this area, the conflict had to be resolved sooner or later. Nevertheless, the civil registration laws were not adopted by 1940 , and this was also determined by the active opposition of the Catholic Church, and, from the religious point of view, the quite homogeneous position of most of society.

The absence of civil registration encouraged legal nihilism: ways were sought to circumvent the law, to create precedents, or simply ignore the existing legal norms, pending their replacement. On the other hand, the persistent commotion over civil registration, the two decades of controversy (always intensified by the political press, brochures aimed at the people, and the sermons of priests) radicalised society, especially the intelligentsia. The Lithuanian Libertines Society, establishing chapters and civilian cemeteries in towns and villages, emerged and grew. Its initiatives, civil marriage in the Klaipeda region or abroad, the establishment of freethinkers' cemeteries, were rare phenomena, exceptions to the rule. Nevertheless, their presence testifies to the emergence of new phenomena, social changes, the trend towards the liberalisation of traditional conservative Catholic culture. Church registration was maybe not the most important reason for this trend, but was nevertheless one of the factors. 
Author Details

Regina Laukaityte, hum. dr, is a senior researcher in the 20th Century History Department at the Lithuanian Institute of History. Most important areas of study: the history of the churches of Lithuania in the 20th century. The author of several monographs (Lietuvos vienuolijos: XX amžiaus istorijos bruožai) [Monastic Institutions of Lithuania: Features of their History in the Twentieth Century] (1997); Stačiatikiu Bažnyčia Lietuvoje XX amžiuje [The Orthodox Church in Lithuania in the Twentieth Century] (2003); Lietuvos Bažnyčios vokiečiu okupacijos metais (1941-1944) [Lithuanian Churches under German Occupation (1941-1944)] (2010); Marijos Nekaltojo Prasidejimo vargdieniu seseru vienuolijos šaka Amerikoje [The North American Branch of the Sisters of the Immaculate Conception of the Poor] (2012).

Address: Lithuanian Institute of History, Kražių g. 5, Vilnius, LT-01108

Email: laukaityte@istorija.lt

VISUOMENÉ BE CIVILINĖS METRIKACIJOS (1918-1940 M.): IŠEITYS IR PASEKMĖS

Santrauka

REGINA LAUKAITYTE

1918-1940 m. Lietuvos Respublikoje nebuvo valstybinès civilinès būklès aktų registracijos, t.y. teisę registruoti gimimo, jungtuvių ir mirties aktus turèjo tik valstybės pripažintų tikybų dvasininkai. Tokia situacija kèlè daug keblumų negausių „nepripažintų“ bendruomenių tikintiesiems, nereligingiems piliečiams. Straipsnyje analizuojamas skirtingoms politinèms jègoms atstovavusių vyriausybių požiūris ị civilinę metrikaciją; aiškinamasi, kokias išeitis iš susidariusios padèties rado visuomenè, - būtent kaip, nesant civilinès būklès aktų valstybinès metrikacijos sistemos, „nepripažintų“ bendruomenių tikintieji ir nereligingi gyventojai vis dèlto tuokdavosi, iteisindavo vaikus ir laidodavo mirusiuosius; taip pat aptariamos bažnytinės metrikacijos vyravimo pasekmès.

Visos 1918-1940 m. Lietuvos valstybę valdžiusios dešiniosios bei kairiosios politinès partijos ịvertino civilinès metrikacijos ịvedimo svarbą - visos žadejjo ir ruošèsi priimti ją reglamentuojančius îstatymus. Labiausiai tai daryti vertè padètis, kai dalis piliečių neturèjo galimybès registruoti civilinès būklès aktų, ir tai, kad valstybè ir Bažnyčia skirtingai traktavo juridinius aktus (faktiškai sprendè su katalikų jungtuvėmis susijusias bylas ir nepripažino Klaipėdos krašte ar užsienyje sudarytų civilinių santuokų). Tad šioje srityje 
buvo subrendusi krizè, konfliktas anksčiau ar vèliau turèjo būti sprendžiamas. Vis dèlto iki 1940 m. civilinès metrikacijos įstatymai nebuvo priimti, tai lėmè ir aktyvus Katalikų Bažnyčios priešinimasis, ir religiniu požiūriu gana vienalytės visuomenès daugumos pozicija.

Civilinès metrikacijos nebuvimas skatino juridinị nihilizmą - ieškota būdų apeiti ịstatymus, kurti precedentus arba tiesiog nepaisyti galiojančių įstatymų normų, laukiant jų pakeitimo. Kita vertus, įsisenèjęs ažiotažas dèl civilinès metrikacijos, du dešimtmečius trukęs ginčas (nuolat kurstomas partineje spaudoje ir liaudžiai skirtose brošiūrose, kunigų pamoksluose) radikalizavo visuomenę, ypač inteligentiją. Atsirado ir sèkmingai išaugo Lietuvos laisvamanių etinès kultūros draugija, steigusi skyrius ir civilines kapines miesteliuose, kaimuose. Jos skatintos iniciatyvos - civilinès santuokos Klaipèdos krašte ar užsienyje, laisvamanių kapinių steigimas - buvo reti reiškiniai, išimtys. Vis dèlto jų buvimas liudija socialinius pokyčius - tradicinès konservatyvios katalikiškosios kultūros liberalejjimo tendenciją. Bažnytinè metrikacija gal ir nebuvo svarbiausia tokios tendencijos priežastis, vis dèlto - vienas veiksnių. 